\title{
Development of the strategic financial engineering accounting system ${ }^{* *}$
}

\author{
Nelia Proskurina ${ }^{1}$, Viktoriia Gryn ${ }^{2}$ \\ ${ }^{I}$ Doctor of Economics, Professor, Acting Head of the Department of Accounting and Taxation \\ ${ }^{2}$ Candidate of Economic Sciences, Associate Professor of the Department of Accounting and Taxation \\ Zaporizhzhia National University
}

JEL Classification: $M 14$

\begin{abstract}
The necessity of developing information add-ins to the financial accounting system for the formation of additional strategic information is revealed. Additional types of information needed by stakeholders to make strategic decisions are highlighted. Historical aspects of the emergence of strategic accounting engineering are considered. The main ways of developing engineering principles for building a strategic financial accounting system are highlighted and analyzed. The sequence of formation of derivative strategic balance sheets is developed through the development of an engineering system of financial accounting of an enterprise, which includes the following stages: 1) aggregation of elements of financial statements; 2) implementation of corrective operations; 3) implementation of transformational (hedged) operations; 4) implementation of strategic operations; 5) implementation of hypothetical operations. The necessary sources of information for forming a derivative strategic balance sheet of an enterprise are disclosed. A model for generating a derivative strategic balance sheet of an enterprise has been developed, which allows calculating engineering indicators (net assets, net assets after adjustments, hedged net assets, strategic net assets, net liabilities) for analyzing the results of strategic enterprise management.
\end{abstract}

Keywords: financial accounting, accounting engineering, strategic financial engineering accounting, derivative strategic balance sheet

\section{Introduction}

In the modern conditions of development of financial accounting technology based on the use of IAS / IFRS, as well as taking into account the capabilities of modern computer accounting and information systems, it has become possible to develop and actively implement engineering add-ins. Such engineering add-ins to the current financial accounting system, include the expansion of the accounting method, partial overcoming of certain theoretical and methodological limitations of the accounting system of the enterprise, provide the formation of forecast / strategic engineering reporting on the future of the enterprise based

Corresponding author:

${ }^{1}$ E-mail addresses: profauditzp@ukr.net

ORCID: https://orcid.org/oooo-0oo1-8674-1720

${ }^{2}$ E-mail: viktoriya_grin@ukr.net

ORCID: https://orcid.org/oooo-0oo2-6758-7374

(C) 2021 N.Proskurina, V.Gryn

doi: https://doi.org/10.26642/ppa-2021-1(3)-22-31 
on the construction of various scenarios and simulation at the present moment of future or forecast economic actions and events. Such add-ins are based on the concept of financial engineering accounting, the main purpose of which is to form engineering reports. One of the types of engineering reporting is derived strategic engineering reporting, which can be considered as a source of information for making strategic management decisions by subjects of strategic management of the enterprise, as well as various types of external entities.

The main result of implementing engineering in the financial accounting system from the point of view of the strategic management system is the formation of various types of derivative balance sheets, which allow you to disclose strategic, hypothetical (conditional) and forecast information about the company's activities, which can be used in the process of making managerial decisions, and also allow you to analyze the strategy of an individual enterprise based on changes in basic indicators. Such reports are formed by engineering transformation of the traditional balance sheet of the enterprise (statement of financial position) through the use of engineering accounting methods.

According to V.V. Lesniak, the system of derivative balance sheets acts as an accounting and analytical tool for the development, reflection and implementation of the company's strategy and provides: accounting for external factors; reflecting the alternativeness (multivariance) of strategic decisions with appropriate analytics; accounting for assets and liabilities arising as a result of the implementation of the adopted strategy; accounting for assets and liabilities arising as a result of changes (adjustments) of the strategy, due to the use of a new strategy; reflecting hypothetical processes of conditional sale of assets and satisfaction of liabilities in the prices necessary for decision-making (market, collateral, fair, liquidation, etc.) [19, p. 221-222]. The purpose of constructing derivative balance sheets is to overcome the existing «information vacuum» between decision-making entities and accounting information generation entities, which in their actions are significantly limited by both regulatory requirements of accounting standards, internal accounting policies, and the requirement for non-disclosure of important confidential information about the company's activities. This problem also concerns information support for the implementation of strategic analysis of the enterprise, the effective implementation of which requires deeper and more predictive accounting information. The level of quality should be determined based on the degree of satisfaction of the needs and requests of decision makers.

\section{Literature review.}

The basic theoretical foundations of accounting engineering theory are described in the fundamental work of Prof. V.I. Tkach and M.V. Shumeiko [25] and developed in the works of representatives of the engineering accounting school (I.M. Bohataia, T.O. Hrafova, O.M. Yevstafieva, S.N. Zemliakova, L.O. Zimakova, G.E. Krokhicheva, D.V. Kursieiev, O.V. Kuznetsova, V.V. Lesniak, I.V. Lesniak, H.I. Milokhina, I.M. Tkach, M.M. Skoriev, T.M. Muzyka, A.M. Shchemeliev et al.).

Today, there are also isolated attempts to analyze the features of using engineering methodology in accounting in some works of Ukrainian scientists (M.V. Bolduiev, Yu.Yu. Biloshytska, A.M. Herasymovych, M.V. Koriahin, V.K. Makarovych, P.O. Kutsyk, O.H. Sydorchuk, I.A. Yukhymenko-Nazaruk), and there are thorough developments and proposals for the development of the forecast accounting function through the use of engineering accounting theory - V.M. Zhuk, R.F. Brukhanskyi, I.B. Sadovska, I.A. Herasymovych. The above authors devoted monographic studies to the development of the financial accounting system in the enterprise management system based on the use of engineering tools, in particular, justifying the prospects for its use in the strategic management system. At the same time, insufficient attention is currently paid to the use of engineering methodology from the point of view of building a strategically oriented accounting system at enterprises.

\section{The identification of previously unresolved issues and the formulation of research hypotheses.}

The development and implementation of any strategy in modern conditions of development of management systems involves the use of strategic thinking and strategic communication (internal and external), aimed at creating value and implementing strategic control. Despite the significant role of financial accounting for the development and implementation of strategies of the enterprise, in particular, in terms of the formation of a system of necessary indicators (cash flow; profitability of types, areas of activity, divisions, etc.; the efficiency of using current and non-current capital; the structure of the capital used; indicators of the dynamics of activities of the enterprise and markets; the level of tax burden, etc.) to establish the financial goals of the enterprise, effective cost management and for information support of risk management and control of the implementation of the strategy, information support for such processes can not be properly provided with the help of the financial accounting model used, based on Ukrainian Accounting standards or IAS / IFRS systems and GAAP US, because its creation did not take into account the existing information needs of internal and external stakeholders making strategic decisions. In particular, from the point of view of stakeholders to make strategic decisions, in addition to the information provided in the financial statements and notes to it, information is essential about:

- $\quad$ strategic objects, i.e. those resources of the enterprise, on the effective use of which the success of its implementation depends;

- main strategic risks of the internal and external environment of the enterprise;

- $\quad$ status of implementation of strategic initiatives and established strategic plans;

- professional judgments and accounting policies of the enterprise, implemented taking into account the strategic context of the enterprise's activities;

- $\quad$ prospects for the development of the enterprise based on currently available data on future operations and potential expenses and revenues of the enterprise. 
All the above proposals for disclosure of additional information necessary for making strategic management decisions can be justified by the need to overcome the following theoretical and methodological limitations of the financial accounting system: 1) temporary reorientation; 2) expansion of the subject of financial accounting as a practical activity; 3) object-methodological reconstruction of the financial accounting system. Overcoming them will expand the strategic accounting information space of the enterprise and increase the effectiveness of information support for the process of developing new strategies of the enterprise in the context of disturbances in the external environment and the appearance of internal risks, taking into account the long-term goals of the enterprise, as well as contribute to improving the effectiveness of strategic control.

One of these tools for the development of the financial accounting system, which allows improving the strategic accounting communications of the enterprise, is the concept of engineering accounting, which forms the theoretical and methodological foundations for the formation of engineering add-ins. The main hypothesis of the study is that in order to form additional information necessary for strategic decision-making by internal and external stakeholders, it is necessary to form a strategic engineering add-in to the current financial accounting system based on the use of the accounting engineering concept.

\section{Research methodology and methods.}

The methodological basis of the research for writing the article was the engineering theory of accounting, which includes the usage of engineering tools for the formation of additional information add-ins to the financial accounting system. The process of forming an engineering add-in to the financial accounting system basically contains the application of a modeling method, which includes the development of a derivative strategic balance sheet based on the adjustment of indicators of the financial accounting system, their content (estimated) transformation and addition.

The use of engineering methods in the financial accounting system allows to adjust, transform and supplement existing information in the financial statements in order to give it greater strategic significance in the following areas:

- $\quad$ in terms of the scope of coverage of business operations reflected in the financial accounting system - by including previously unaccounted objects and operations in their composition;

- $\quad$ according to estimated parameters - by using other types of estimates (fair, market, collateral, liquidation, replacement value, etc.) to form derivative balance sheets of the enterprise;

- $\quad$ by time parameters - by accounting reflection of hypothetical business operations (future events, conditional operations for the sale of assets and hypothetical satisfaction of liabilities);

- $\quad$ according to the parameters of alternatives - by taking into account various types of alternative opportunities for implementing the company's activities, in particular, strategic alternatives;

- by structural units of the enterprise (directions, types or segments of activity, strategic business units, space fractals, etc.).

\section{Main results.}

The direct role of engineering in the formation of the strategic accounting system was first described by Prof. I.M. Bohata [5, p. 98-100] in 2001, who developed a methodology for strategic accounting of enterprise property in order to design derivative balance sheets. Such proposals, according to the author, made it possible to improve the assessment of the company's development prospects by disclosing internal and external strategic balance sheets, which should provide better accounting information from the point of view of strategic management. An appropriate level of quality should be ensured both by properly adjusting existing accounting data, and by adding new elements to them and taking into account the strategic context of enterprise development, that is, including data on the future of the enterprise based on making forecasts and taking into account the impact of risks.

In 2007, Prof. I.M. Bohata [4, p. 42] based on the analysis of the practical activity of the enterprise presented for consideration the direct concept of strategic accounting in commercial organizations, which included monitoring, methodological and generalizing stages, the quintessence of which was the construction of a strategic derivative balance sheet. This report summarizes all estimated, meaningful and temporary adjustments to information from the financial accounting system, eliminating its main shortcomings, and is a significant source of information for making strategic decisions.

In the future, the engineering principles of building a strategic accounting system at enterprises are developed in three main ways (Fig. 1).

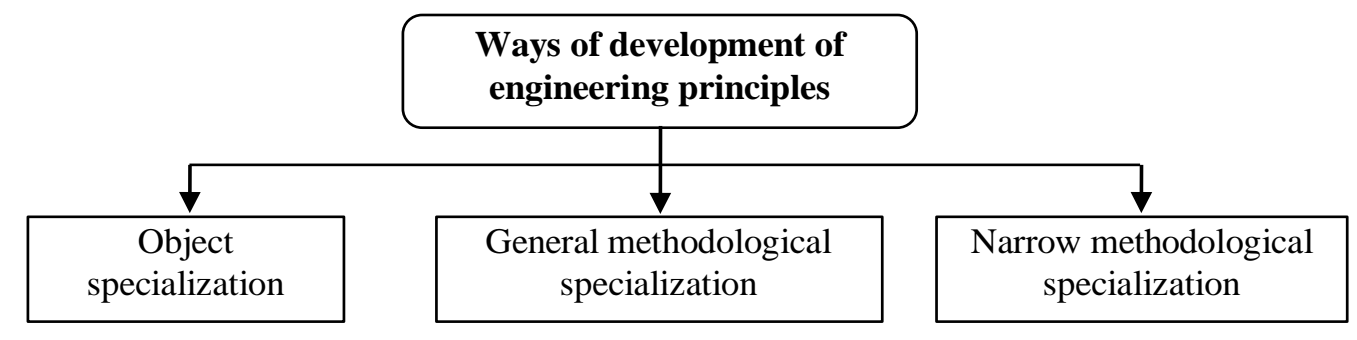

Fig. 1. Ways to develop engineering principles for building a strategic accounting system 
1) Object specialization - a direction that develops due to the works of individual scientists who study the problems of strategic accounting of particular accounting objects or areas of activity of enterprises. Such studies use existing developments in the field of engineering theory, which are projected on the current methodology of particular accounting objects or areas of activity of enterprises and take into account their specific features in order to form more effective information support for making strategic decisions. Thus, O.M. Shchemeliev [26, p. 33-34] justified the expediency of constructing a strategic derivative balance sheet in order to determine the size of strategic assets based on improving the methodology for accounting for enterprise innovations. Zimakova L.O. [15, p. 31-32] proposed the need for strategic accounting at the enterprise based on the use of engineering tools that ensure the formation of derivative balance sheets for making operational, tactical and strategic decisions. Similar proposals in the context of various accounting objects and areas of activity of the enterprise are given in the research of a significant number of scientists (T.M. Muzyka - objects of external management of agricultural enterprises [21, p. 231], V.V. Lesniak - factors of external influence [19, p. 221], T.O. Hrafova - intellectual capital [9, p. 42], E.S. Arakeliants - factors of the external environment [1], O.M. Yevstafieva - internal and external factors affecting the cost [11, p. 4], O.V. Yevsiukova, O.A. Yurieva [13, p. 3-4] - activity of pawnshops, etc.).

2) General methodological specialization includes the improvement of accounting engineering tools (new types of accounting aggregates, new types of accounting entries, new types of derivative reports, etc.) and is mainly carried out by representatives of the Rostov accounting School (M.V. Shumeiko - concept of accounting engineering tools [25, p. 75], T.O. Hrafova - methodology of using accounting engineering tools in transaction accounting [8, p. 25-26], etc.). Development of ideas of Prof. V.I. Tkach and Prof. I.M Bohata in the field of engineering theory of accounting took place in the dissertation research of their students, which ultimately resulted in the formation of the engineering concept of resource potential management - «Resoursum» [22], which summarizes the best practices of representatives of the Rostov Accounting School. This online service allows to manage the economic processes and resource potential of the enterprise based on the use of engineering tools, including a strategic context, providing the formation of various types of derivative balance sheets.

3) Narrow-methodological specialization includes the formation of strategic engineering tools, which allows the transformation of the company's financial statements in the direction of ensuring its strategic orientation. As noted by E.S. Arakeliants, strategic engineering tools are represented by a system of derived balance sheets - secondary balance sheets of strategic direction, integrated consolidated balance sheets, strategic statements and reports: accounting; control; analytical; consolidated integrated nature [2, p. 57-58]. Unlike general-purpose accounting engineering tools, strategic engineering tools are used exclusively for forming effective information support for the strategic management of an enterprise and disclosing the necessary information for making strategic decisions by external users. As a result of the analysis of scientists' proposals, it was established that it includes not only strategic derivative balance sheets, as noted by E.S. Arakeliants, but also the necessary means of their formation - a strategic structured chart of accounts, strategic adjustments to financial statements, strategic transactions and strategic accounting estimates.

The analysis of the best practices of modern scientists in the field of engineering accounting theory allows us to state the existence of deep methodological developments that can be used as the basis for the formation of an engineering financial accounting system for the formation of effective strategic accounting communications at domestic enterprises. Engineering tools are constantly being improved within the framework of the identified three areas, which generally contributes to bringing the engineering system of strategic accounting closer to the changing and growing needs of users of strategic information. Strategic derivative balance sheets, as the main product of such a system, can be considered as one of the new forms of accounting communication, which provides information interaction of enterprise management with internal and external stakeholders, forming their ideas about the strategic development of the enterprise and thus influencing their decisions. They allow to take into account the impact of contingent assets and liabilities, strategically important resources of the enterprise and environmental factors on the results of implementing the strategy chosen by the enterprise in the form of indicators of net assets and net liabilities, which are determined in this report.

That is why N.I. Yefimova calls the derived balance sheet a tool for strategic analysis of the organization's sustainability, since it is aimed at determining the value of the enterprise, taking into account a number of external factors when implementing the chosen strategy. The formation of strategic derivative balance sheets makes it possible to develop scenarios for the development of the situation and assess the stability of the enterprise. Scenarios also describe possible future states of various factors affecting sustainability, such as industry structure, competition, market and buyers, technology, legislation, investment, exchange rate changes, etc. [14, p. 44]. Thus, depending on the possible scenarios for the occurrence of hypothetical events, several variants of derived strategic balance sheets can be formed for the needs of users, which will characterize various variants of their occurrence that are of strategic importance for the enterprise.

According to Yu.V. Denysevych [10] theoretical and methodological aspects of the formation of derivative balance sheets of an enterprise are a separate area of accounting research, which is characterized by evolutionary-adaptive balance theory. This theory is considered a separate new branch of balance science, which has its own method, principles and ability to organize the management process of a modern organization in conditions of uncertainty and risk. The presence of its own developed theoretical and methodological foundations also confirms the feasibility of using accounting engineering to increase the level of information support for the strategic decision-making process at the enterprise.

Based on the analysis of the views of foreign and domestic researchers on the formation of engineering add-ins to the accounting system, the following sequence of formation of derivative strategic balance sheets is proposed by developing an engineering system for financial accounting of an enterprise (Fig. 2). 


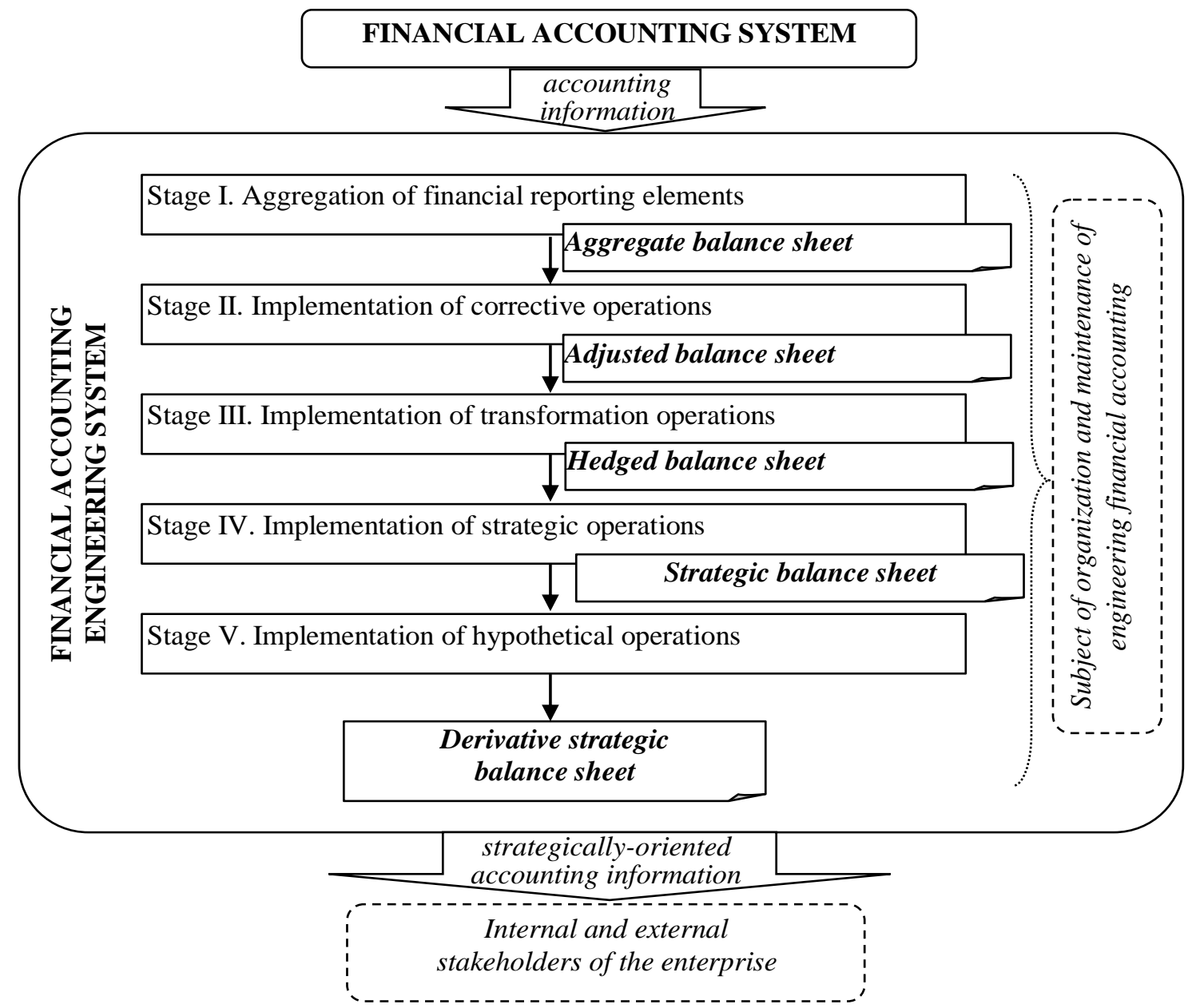

Fig. 2. Sequence of formation of the derivative strategic balance sheet of the enterprise in the engineering financial accounting system

For effective implementation of the proposed sequence of formation of the derivative strategic balance sheet of the enterprise (Fig. 2) it is necessary to use:

1) information from the financial accounting system, which will serve as the basic operator and the basis for structuring reporting items into the necessary aggregates;

2) a set of engineering tools (charts of accounts, various types of engineering reports, etc);

3) special accounting engineering procedures (various types of engineering operations).

The proposed model of functioning of the engineering system of financial accounting takes into account the conceptual foundations of the engineering theory of accounting, as well as the proposals of domestic scientists who tried to adapt the principles of this theory in the form of the development of the methodology of engineering accounting in Ukraine R.F. Brukhanskyi [6, p. 185-207], M.V. Koriahina and P.O. Kutsyk [18, p. 30-32], A.M. Herasymovych and I.A. Herasymovych [7, p. 9-12]. At the same time, the proposed methodology for forming a derivative strategic balance sheet of an enterprise is based on the author's vision regarding the use of engineering tools and understanding the essence of engineering procedures, as well as the author's best practices in terms of using the concept of strategic assets of the enterprise and the proposed approaches to their assessment, which are important from the point of view of making strategic decisions.

Stage I. Aggregation of financial reporting elements. Since the engineering information add-in to the financial accounting system is not a full-fledged accounting system that provides a full reflection of the economic activity of the enterprise with all analytical sections, to ensure its functioning, it is necessary to aggregate (consolidate) elements of financial statements in such a way as to ensure the formation of engineering accounting information that will meet the requirements of strategic management entities. Today, researchers offer various options for aggregating elements of financial statements - a strategically structured chart of accounts, components of the balance sheet equation (assets, liabilities, equity), a specialized set of strategic indicators, and so on.

In our opinion, the main sections of the company's balance sheet should be used as aggregates of the engineering accounting system, which will allow us to harmonize the engineering methodology with the financial accounting methodology and the existing author's proposals for improving the methodology for accounting for strategic assets of the enterprise (Section I. Noncurrent assets; Section II. Current assets; Section III. Equity; section IV. Long-term liabilities and collateral; Section V. Current liabilities and collateral). As part of non-current assets, the aggregated chart of accounts should also highlight strategic noncurrent assets and other non-current assets in order to disclose engineering accounting information about those elements that are 
most important from the point of view of strategic decision-making. In addition, depending on the available information needs of strategic management entities and the specifics of the enterprise's activities, subaccounts and analytical accounts can be allocated within the formed aggregates to form more detailed engineering accounting information.

As a result of aggregation of the components of the balance sheet by its sections, an aggregated balance sheet is compiled, on the basis of which the net asset indicator of the enterprise is calculated, as one of the main indicators that will be used to analyze the impact of various types of operations on the results of implementing the strategy chosen by the enterprise in a certain time period.

Stage II. The implementation of corrective operations implies the need to bring the indicators of the aggregated balance sheet of the enterprise to the real state of affairs, that is, to the real economic state of the enterprise, and not its current accounting model. The need for adjustments is determined by the existing methodological limitations laid down in the basis of accounting standards systems (Ukrainian Accounting Standards, IAS / IFRS), as a result of which the book value of an enterprise significantly differs from its market value, as evidenced by the emergence of significant amount of goodwill as a result of mergers and acquisitions of enterprises in recent years. Thus, according to stock market analysts, the value of intangible assets in companies included in the S\&P 500 rating has increased from 1122 billion dollars since 1975 up to 21 trillion dollars in 2018 [27], however, most of these assets are either not reflected in the current accounting system at all, or are estimated on the basis of a cost-based approach, which also does not reflect their real value and makes it difficult for internal and external users to make effective strategic decisions based on such information. As a result, only comparing the book value with the market value of an enterprise can help investors determine whether its market prospects are overvalued or undervalued. Therefore, the implementation of adjustments to the indicators of the aggregated balance sheet is aimed at bringing the accounting estimate of the value of the enterprise closer to its real market value, which is important from the point of view of making strategic decisions.

If M.V. Koriahin and P.O. Kutsyk [18, p. 30], A.M. Herasymovych and I.A. Herasymovych [7, p. 9] propose to adjust the historical value of objects to its market values, then according to R.F. Brukhanskyi [6, p. 194-196] it is possible to make three types of adjustments: 1) cost adjustments (revaluation of balance sheet items, introduction of off-balance sheet elements (conditional assets and liabilities) into accounting objects)); 2) adjustments due to changes in strategy; 3) adjustments by adding new objects of accounting in accordance with the needs and requests of strategic management. In Particular, L.O. Zimakova refers to such new objects the following: labor resources; business reputation; trademark; brand; prospects for the development of the company (geographical and economic segments available to the company, the development of the company, etc.) [16, p. 72]. Such adjustments are made by capitalizing the costs incurred by the enterprise for the creation of such objects, which implies the need for their preliminary identification by the subjects of engineering financial accounting.

Yevstafieva O.M. [12, p. 52] and Hrafova T.O. [8, p. 33] to the system of balance sheet adjustments includes off-balance sheet items, conditional assets and liabilities, conditional facts of economic activity, subsidies, dotations, subventions, etc., the use of which allows you to reflect the real financial condition of the enterprise in the adjusted balance sheet. The above-mentioned objects can be subjects of engineering financial accounting both in the course of the current activities of the enterprise, in particular, as factors of formation of the value of the enterprise that do not have corresponding accounting analogues, and as a result of internal and external audit of the enterprise.

We believe that when making corrective records, we should proceed from the information needs of the subjects who will make strategic decisions. Their main purpose is to reflect in the adjusted balance sheet such information that is not reflected in the financial statements, but is important from the point of view of reflecting the features of the strategic development of the enterprise. For example, if information about possible changes in the market value of an enterprise in the future plays an important role for such entities, then to establish such hypothetical changes, it is necessary to bring the basic operator - elements of the aggregated balance sheet - to their market value using the above ways, both through revaluation of existing objects of the aggregated balance sheet based on the application of fair value, and by adding new conditional and capitalized accounting objects. Thus, based on the needs of strategic management entities, the value of strategic assets of the enterprise should be adjusted by revaluing them at restorative cost or replacement cost, for which the available information from the proposed report on strategic assets of the enterprise can be used. Based on the results of the adjustments made, an adjusted balance sheet is formed, the calculated net asset value on the basis of which should reflect the real value of the enterprise.

Stage III. The implementation of transformation operations involves the implementation of synthetic business operations aimed at transforming the classical accounting reality of the enterprise through various types of engineering procedures. The list of such procedures was systematized by R.F. Brukhanskyi, which include the following: transformational accounting entries (I.M. Bohataia); fractal accounting entries (L.R. Lilieieva); substantive entries (Yu.A. Ilshtein); records on economic situations (O.Y. Rusyna); immunization accounting entries (O.M. Shchemeliev); immunization balance sheets (L.N. Kuznetsova, Yu.V. Denysevych); conducting a survey of risky assets (E.L. Arkhipov); hedged records (E.L. Arkhipov) [3, p. 194-196], etc. And this is not an exhaustive list, since researchers are currently developing new directions for transforming the accounting reflection of the company's activities. Depending on the use of a particular type of business operations, the corresponding type of derivative balance sheet report is formed, aimed at forming information support for specific types of strategic decisions. To manage the strategic solvency of the enterprise, immunization business operations will be used, ensuring the formation of an immunization derivative balance sheet report, for strategic management of the reserve system of the enterprise - hedged business operations, ensuring the formation of a hedged derivative balance sheet report, for managing the financial condition of the enterprise - economic situations, ensuring the formation of a situational derivative balance sheet report, etc.

Since transformation operations are more concerned with the ability of the financial accounting system itself to change, rather than reflecting changes in the enterprise's accounting, the most promising direction from the point of view of strategic management is the implementation of such operations in relation to the system of accounting reserves (hedged business 
operations) and the formation of a hedged derivative balance sheet. Thus, A.M. Herasymovych and I.A. Herasymovych [7, p. 9] proposed to carry out operations for hedging (protection) from risks and operations based on existing risks, which in their opinion will contribute to improving enterprise management based on accounting data.

Direct examples of transformational hedged operations will be operations related to the creation of reserves by an enterprise in order to protect the enterprise's activities from changes that may occur in the future. For Example, O.V. Yevsiukova, O.A. Yurieva proposed to reflect operations related to additional accrual or creation of separate reserves, and the formation of insurance reserves in the form of future guarantees of compensation for losses subject to insurance [13, p. 6], E.L. Arkhipov hedged operations for each of the 15 allocated aggregates of the enterprise's reserve system (asset and liability management, insurance, guarantee, blocking, etc.) [3, p. 260]. Taking into account the above proposals for identifying strategic assets of the enterprise, it is advisable to create accounting reserves to cover the costs of their reproduction (restoration, replacement), which will thus preserve the strategic competitive advantages of the enterprise.

As a result of such operations, a hedged derivative balance sheet is formed, which is a source of information support for strategic risk management and the reserve system of the enterprise. Based on the formed indicator, it is possible to determine the indicator of net hedged assets of the enterprise and compare it with the indicator of basic net assets, determine the financial risk zones that will be the basis for making decisions on the strategic development of the reserve system of the enterprise.

Stage IV. The implementation of strategic operations involves reflecting business operations that do not directly relate to the activities of the enterprise and adjusting the indicators of its financial statements, but are related to what mainly remains outside the accounting observation system - the external environment of the enterprise. The external environment, which is mostly not the object of attention of financial accounting entities today, at the same time plays a decisive role in the process of developing new and implementing existing enterprise strategies. The need to reflect its elements in the financial accounting system is one of the reasons for the emergence of a strategic accounting system, which should overcome this gap and ensure the formation of up-to-date accounting information about existing and potential changes in the external environment.

The need for reflection in strategic accounting was first noted by Prof. I.M. Bohataia [4, p. 42], and has already established in more detail the role of strategic accounting in identifying elements of the external environment and registering them L.O. Ivashynenko (student of I.M. Bohataia), which in general understood strategic accounting as a system for monitoring the external macro-environment of the enterprise (information about the external environment, interest rate forecast, GDP forecast, inflation rate forecast, product life cycle forecast, demand forecast for products, works, services, stock quotes, etc.) [17, p.12]. This approach made it possible to clearly define the further general direction of development of strategic accounting - as an expansion of the subject of traditional accounting by including elements of the external environment of the enterprise, which later became actively used among scientists dealing with the problems of information support for strategic management. For example, L.O. Zimakova believes that the use of accounting engineering tools for Strategic accounting is possible only on the basis of collected external information about buyers, suppliers, competitors, sales by segment, value chains, human resources, areas of strategic activity, etc. [15, p. 31].

Thus, two types of strategic engineering business operations can be performed to build a strategic balance sheet:

1) registration of new environmental objects that are not yet reflected in the aggregates of the corrected engineering reporting of the enterprise. An example of such an operation can be the emergence of new types of resources of an enterprise that are not directly related to its specific efforts (clear direction of costs), but provide competitive advantages. In particular, recognition of the proper level of product quality by external organizations (winning a competition, exhibition, etc.), obtaining a certificate, diploma, environmental labeling, etc. is an example of the emergence of a new strategically important resource for an enterprise, which should be reflected in the engineering accounting system.

2) taking into account the impact of the external environment on objects already reflected in the engineering accounting system, taking into account the time horizon within which the strategic balance sheet will be formed. Modern researchers identify a significant number of such existing and potential factors through which such an impact is carried out within different time horizons. Thus, V.V. Lesniak takes into account changes in such external factors: changes in the exchange rate, the refinancing rate of the central bank, tax and customs policy, the competitive situation in the industry, changes in the social sphere, etc. [20, p.18], O.M. Yevstafieva suggests reflecting the impact of an increase and decrease in the interest rate relative to the financial capital of the enterprise, an increase or decrease in the tax burden relative to accrued tax liabilities, the impact of changes in the state's tax policy on production costs $[11$, p. 6].

Based on the implementation of strategic engineering business operations, a strategic balance sheet is formed, from which it is possible to calculate the value of the indicator of net strategic engineering assets of the enterprise, already on the basis of the analysis of which the company's strategy can be adjusted and more optimal options for its further development can be selected. In general, such a report allows us to determine the real value of an enterprise as an integral economic complex operating under the dynamic influence of environmental factors, determining its strategic situation using the indicator of net strategic engineering assets.

Stage $V$. The implementation of hypothetical operations is based on the ideas of T. Limperh regarding the possibility of hypothetical realization of assets and satisfaction of long-term and current liabilities in estimates that are adequate from the point of view of strategic decision-making entities. The most acceptable application of fair value in modern conditions of development of accounting valuation methodology for performing such hypothetical operations is the use of fair value. In general, scientists also call this approach to summarizing the results of an enterprise's activities the zero balance sheet method, which involves zeroing out balance sheet items by hypothetically converting them (selling them at fair prices) into cash. The method of zeroing balance sheets is currently widely used in the audit practice of European companies to assess the development potential of an enterprise.

The process of forming zero balance sheets actually provides for the need for artificial liquidation of the enterprise at a certain point in time, which allows to calculate the indicator of net liabilities of the enterprise and build a dynamic balance sheet, the 
elements (aggregates) of which are formed as a result of corrective, transformational, strategic and hypothetical business operations. Such a balance sheet consists of net cash in the asset and disaggregated net liabilities on the right side of it - the company's equity and all incremental value. As noted by Prof. V.I. Tkach and H.E. Krokhicheva [24, p. 6], as a result of such a hypothetical sale of assets and satisfaction of liabilities, two situations may arise: 1) a positive net value of the business is obtained, only cash remains in the asset, and net liabilities in the form of a disaggregated indicator of the cost of capital remain in the liability. If the positive net value of the business is greater than the value of net liabilities, then a transaction is made that reflects the increase in value by the difference between the asset and the liability of the balance sheet, if it is less than the value of net liabilities, then a transaction is made that reflects the impairment of the cost of capital of the business; 2) a negative net value of the business is obtained, losses remain in the asset, and negative capital remains in the liability. This situation occurs if the enterprise is unable to repay the existing obligations of the enterprise in real estimates at the expense of the funds available and received from the sale of assets.

From a methodological point of view, first business operations are carried out for the hypothetical sale from the least liquid assets to more liquid assets, and only then there is a hypothetical repayment of long-term and short-term liabilities. In the case of hypothetical sale of assets, there is an increase in the aggregate, which includes cash (current assets), and a decrease in the corresponding aggregates of assets, and in the case of hypothetical repayment of liabilities - a decrease in the aggregate, which includes the corresponding liabilities, and a decrease in the aggregate, which includes cash.

Based on the comparison of the aggregated indicator of enterprise ownership (net assets) and the disaggregated indicator of ownership (net liabilities), it is possible to analyze the efficiency of the enterprise's functioning depending on the intermediate engineering business operations used (transformational, strategic). In particular, based on the proposed sequence of formation of the derivative strategic balance sheet as a result of the analysis of indicators of net assets, adjusted net assets, hedged net assets, strategic net assets and net liabilities, the necessary decisions are made to adjust the company's strategy.

As a result of a detailed analysis of the stages of forming a derived strategic balance sheet, the general model of this process can be presented as follows (Table1).

Presented model for generating a derived strategic balance sheet (Table 1) allows to more clearly disclose the use of engineering instruments and engineering procedures, as well as determine the possibilities of calculating engineering analytical indicators (net assets, net assets after adjustments, hedged net assets, strategic net assets, net liabilities) at specific stages of report formation. Strategic decisions can be made both on the basis of intermediate indicators obtained in the process of forming a derived strategic balance sheet, and as a result of analyzing the indicator of net liabilities of the enterprise, which characterizes the strategic value of the enterprise in the form of a disaggregated indicator of ownership in a fair assessment.

In general, the above proposals for the methodology of forming a derivative strategic balance sheet of an enterprise are an example of the formation of an engineering add-in to the current financial accounting system (financial engineering accounting system), the main task of creating which is to provide more detailed and relevant engineering accounting information of a strategic direction about the company's activities, which can be used by internal and external users to make strategic decisions.

\section{Concluding remarks.}

In order to form additional strategic accounting information about the company's activities, the expediency of forming an engineering add-in to the financial accounting system was justified. The development of such an add-in was based on the engineering theory of accounting, which describes the procedure for practical application of engineering tools and procedures for the formation of engineering reports of an enterprise. After analyzing the views of modern domestic and foreign scientists who study the problems of accounting engineering, it was identified ways to develop the engineering principles of building a strategic accounting system (object specialization, general methodological specialization, narrow-methodological specialization), which confirmed the expediency of building the development of an engineering financial accounting system for the formation of effective strategic accounting communications at domestic enterprises.

The functioning of such a system is based on the methodology of forming a derivative strategic balance sheet of the enterprise, based on the use of the following engineering procedures and appropriate tools:

1) aggregation of elements of financial statements - construction of an aggregated balance sheet;

2) performing corrective operations - building an adjusted balance sheet;

3) Implementation of transformational (hedged) operations - construction of a hedged balance sheet;

4) implementation of strategic operations - building a strategic balance sheet;

5) implementation of hypothetical operations - construction of a derivative strategic balance sheet.

In the process of forming a derivative strategic balance sheet, it becomes possible to calculate a number of new indicators (net assets, net assets after adjustments, hedged net assets, strategic net assets, net liabilities), which provide users with the opportunity to analyze in more detail the features of implementing existing enterprise strategies and determine the prospects for its development in the future. 
Table 1

Model for generating a derivative strategic balance sheet

\begin{tabular}{|c|c|c|c|c|c|c|c|c|c|c|c|c|c|c|c|c|c|c|c|}
\hline \multicolumn{20}{|c|}{ Engineering tools and procedures } \\
\hline \multicolumn{3}{|c|}{$\begin{array}{c}\text { Aggregated } \\
\text { balance } \\
\text { sheet }\end{array}$} & \multicolumn{3}{|c|}{$\begin{array}{l}\text { Corrective } \\
\text { operations }\end{array}$} & \multirow{2}{*}{$\begin{array}{c}\begin{array}{c}\text { Adjusted } \\
\text { balance } \\
\text { sheet }\end{array} \\
\text { Сума }\end{array}$} & \multicolumn{3}{|c|}{$\begin{array}{l}\text { Transformational } \\
\text { operations }\end{array}$} & \multirow[t]{2}{*}{$\begin{array}{c}\text { Hedge } \\
\text { balance } \\
\text { sheet }\end{array}$} & \multicolumn{3}{|c|}{ Strategic operations } & \multirow{2}{*}{$\begin{array}{c}\begin{array}{c}\text { Strategic } \\
\text { balance } \\
\text { sheet }\end{array} \\
\text { Сума }\end{array}$} & \multicolumn{3}{|c|}{$\begin{array}{l}\text { Hypothetical } \\
\text { operations }\end{array}$} & \multicolumn{2}{|c|}{$\begin{array}{c}\text { Derivative } \\
\text { strategic } \\
\text { balance sheet }\end{array}$} \\
\hline Sections & Asset & Liability & $D t$ & $C t$ & Amount & & $D t$ & $C t$ & Сума & & $D t$ & $C t$ & Amount & & Dt & $C t$ & Amount & Asset & Liability \\
\hline $\begin{array}{l}\text { Section I. Non-current } \\
\text { assets }\end{array}$ & & $\mathrm{x}$ & & & & & & & & & & & & & & & & & $\mathrm{x}$ \\
\hline Strategic assets & & $\mathrm{x}$ & & & & & & & & & & & & & & & & & $\mathrm{x}$ \\
\hline Other non-current assets & & $\mathrm{x}$ & & & & & & & & & & & & & & & & & $\mathrm{x}$ \\
\hline Section II. Current assets & & $\mathrm{x}$ & & & & & & & & & & & & & & & & & $\mathrm{x}$ \\
\hline Section III. Equity & $\mathrm{x}$ & & & & & & & & & & & & & & & & & $\mathrm{x}$ & \\
\hline $\begin{array}{l}\text { Section IV. Non-current } \\
\text { liabilities and collateral }\end{array}$ & $\mathrm{x}$ & & & & & & & & & & & & & & & & & $\mathrm{x}$ & \\
\hline $\begin{array}{l}\text { Section V. Current } \\
\text { liabilities and collateral }\end{array}$ & $\mathrm{x}$ & & & & & & & & & & & & & & & & & $\mathrm{x}$ & \\
\hline TOTAL & & & & & & & & & & & & & & & & & & & \\
\hline Net assets & 1 & & & & & 2 & & & & 3 & & & & 4 & & & & & \\
\hline Net liabilities & & & & & & & & & & & & & & & & & & & 5 \\
\hline
\end{tabular}

${ }^{1}$ Net assets.

${ }^{2}$ Net assets after adjustments are made.

${ }^{3}$ Hedged net assets.

${ }^{4}$ Strategic net assets.

${ }^{5}$ Net liabilities. 


\section{References:}

1. Arakel'yants, E.S., «Informatsionnoe obespechenie strategii razvitiya organizatsii», [Online], available at: http://ivdon.ru/magazine/archive/n4y2013/2084

2. Arakel'yants, E.S. (2015), «Formirovanie sistemy uchetno-kontrol'nogo i analiticheskogo obespecheniya strategii razvitiya kommercheskikh organizatsii», Ph.D. Thesis of dissertation, spets. 08.00.12 «Bukhgalterskii uchet, statistika», Rostov-na-Donu, 207 p.

3. Arkhipov, E.L. (2008), «Upravlencheskii uchet rezervnoi sistemy setevogo predpriyatiya», Vestnik Rostovskogo gosudarstvennogo ekonomicheskogo universiteta «RINKh», No. 2, pp. 257-264.

4. Bogataya, I.N. (2007), «Strategicheskii uchet i audit: teoriya i praktika», Fundamental'nye issledovaniya, No. 4, pp. 42-44.

5. Bogataya, I.N. (2001), Strategicheskii uchet sobstvennosti, Feniks, Rostov na-Donu, 320 p.

6. Bruhans'kyj, R.F. (2014), Oblik $i$ analiz u systemi strategichnogo menedzhmentu agrarnogo pidpryjemnyctva, monografija, TNEU, Ternopil', $384 \mathrm{p}$.

7. Gerasymovych, A.M. and Gerasymovych, I.A. (2019), «Sutnist' ta osoblyvosti formuvannja strategichnoi' zvitnosti na osnovi buhgalters'kogo inzhyniryngu», Oblik i finansy, No. 2 (84), pp. 5-12.

8. Grafova, T.O. (2011), «Metodologiya ispol'zovaniya instrumentov bukhgalterskogo inzhiniringa v transaktsionnom uchete», Finansovaya analitika: problemy i resheniya, No. 11 (53), pp. 23-34.

9. Grafova, T.O. (2012), «Metodologiya kompleksnogo ucheta intellektual'nogo kapitala», Abstract of D.Sc. dissertation, spets. 08.00 .12 «Bukhgalterskii uchet, statistika», Rostov-na-Donu, $50 \mathrm{p}$.

10. Denisevich, Yu.V., «Evolyutsionno-adaptivnaya teoriya otchetnosti kak osnova formirovaniya informatsii dlya prinyatiya upravlencheskikh reshenii v kommercheskikh organizatsiyakh», [Online], available at: https://docplayer.ru/50090770-Evolyucionnoadaptivnaya-teoriya-otchetnosti-kak-osnova-formirovaniya-informacii-dlya-prinyatiya-upravlencheskih-resheniy-v-kommercheskihorganizaciyah.html

11. Evstaf'eva, E.N. (2011), «Metodika formirovaniya stragegicheskogo balansovoi otcheta, orientirovannogo na pokazateli stoimosti kapitala», Audit i finansovyi analiz, No. 3, pp. 1-7.

12. Evstaf'eva, E.N. (2009), «Proizvodnye balansovye otchety kak odin iz instrumentov strategicheskogo ucheta sobstvennosti», Finansovye issledovaniya, No. 3, pp. 49-55.

13. Evsyukova, O.V. and Yur'eva, O.A. (2019), «Ispol'zovanie proizvodnykh balansovykh otchetov dlya analiza deyatel'nosti lombardov», Vestnik Evraziiskoi nauki, No. 3, Vol. 11, pp. 1-10.

14. Efimova, N.I. (2010), «Proizvodnyi balansovyi otchet kak instrument strategicheskogo analiza ustoichivosti organizatsii», Problemy sovremennoi ekonomiki, No. 2-3, pp. 42-47.

15. Zimakova, L.A. (2009), «Razvitie teorii i metodologii formirovaniya uchetnykh sistem na osnove internatsional'nykh modelei finansovogo ucheta i kontrolya», Abstract of D.Sc. dissertation, spets. 08.00.12 «Bukhgalterskii uchet, statistika», Michurinsk-naukograd RF, 40 p.

16. Zimakova, L.A. (2009), «Upravlenie sobstvennost'yu na osnove bukhgalterskogo modelirovaniya», Bukhgalterskii uchet, No. 4, pp. 71-73.

17. Ivashinenko, L.O. (2008), «Razvitie metodiki strategicheskogo ucheta v kommercheskikh organizatsiyakh», Abstract of Ph.D. dissertation, spets. 08.00.12 «Bukhgalterskii uchet, statistika», Michurinsk-naukograd RF, 26 p.

18. Korjagin, M.V. and Kucyk, P.O. (2015), «Sutnist' ta osoblyvosti formuvannja strategichnoi' zvitnosti na osnovi buhgalters'kogo inzhyniryngu», Buhgalters'kyj oblik i audyt, No. 7, pp. 26-32.

19. Lesnyak, V.V. (2010), «Instrumentarii strategicheskogo ucheta», Aktual'nye voprosy sovremennoi ekonomicheskoi nauki, Sbornik dokladov mezhdunarodnoi nauchnoi zaochnoi konferentsii, Lipetsk, 20 fevralya 2010 g., in 2nd vol., Vol. 2, in Gorbenko, A.V. (ed.), Izdatel'skii tsentr «De-fakto», Lipetsk, pp. 218-222.

20. Lesnyak, V.V. (2007), «Strategicheskii upravlencheskii uchet na promyshlennykh predpriyatiyakh: kontseptual'nyi podkhod, modelirovanie i organizatsiya», Abstract of Ph.D. dissertation, spets. 08.00.12 «Bukhgalterskii uchet, statistika», Krasnodar, 24 p.

21. Muzyka, T.N. (2010), «Strategicheskii uchet ob"ektov vneshnego upravleniya v sel'skokhozyaistvennykh organizatsiyakh», Aktual'nye voprosy sovremennoi ekonomicheskoi nauki, Sbornik dokladov mezhdunarodnoi nauchnoi zaochnoi konferentsii, Lipetsk, 20 fevralya 2010 g., in 2nd vol., Vol. 2, in Gorbenko, A.V. (ed.), Izdatel'skii tsentr «De-fakto», Lipetsk, pp. 231-236.

22. RESOURSUM, «Inzhiniringovoe upravlenie resursnym potentsialom», [Online], available at: http://resoursum.ru/

23. Tkach, V.I. and Shumeiko, M.V. (2013), «Inzhiniringovyi bukhgalterskii uchet: stanovlenie i razvitie teorii», Mezhdunarodnyi bukhgalterskii uchet, No. 46 (292), pp. 2-8.

24. Tkach, V.I. and Krokhicheva, G.E. (2004), «Sistema nulevykh proizvodnykh balansovykh otchetov i ikh ispol'zovanie v upravlenii», Ekonomicheskii analiz: teoriya i praktika, No. 12 (27), pp. 6-13.

25. Shumeiko, M.V. (2012), «Kontseptsiya instrumentov bukhgalterskogo inzhiniringa», Terra Economicus, Vol. 10, No. 1, Part 2, pp. $72-77$.

26. Shchemelev, A.N. (2007), «Strategicheskii uchet innovatsii v kommercheskikh organizatsiyakh», Abstract of D.Sc. dissertation, spets. 08.00.12 «Bukhgalterskii uchet, statistika», Rostov-na-Donu, 43 p.

27. Ali, A., «The Soaring Value of Intangible Assets in the S\&P 500», [Online], available at: https://www.visualcapitalist.com/the-soaringvalue-of-intangible-assets-in-the-sp-500/

\footnotetext{
** How to cite this article: Proskurina N., Gryn V. Development of the strategic financial engineering accounting system. Public Policy and Accounting. 2021, Vol. 1 (3). https://doi.org/10.26642/ppa-2021-1(3)-22-31.
} 